\title{
THE BANKING SECTOR AND RECOVERY IN THE EU ECONOMY
}

\section{Ray Barrell,* Tatiana Fic,* John Fitz Gerald,** Ali Orazgani* and Rachel Whitworth*}

Banks within Europe have become larger and more international as Europe has moved towards a unified financial services market, but this trend has been reversed since the crisis. In order to establish the effect of these structural changes on output in Europe, we use a micro data set to investigate the impact of size (as measured by asset size) on banks' net interest margins. We show that larger banks offer lower borrowing costs for firms, which raises sustainable output. We then use NiGEM to look at the impact of banks becoming smaller and moving back into their home territory. We investigate the impacts on output according to country size, showing that the effects are generally larger in small countries, and also larger in economies that are more dependent on bank finance for their business investment decisions.

Keywords: Net interest margins; bank size; European financial integration;

economic growth; bank regulation

JEL Classifications: E44; GI0; G28

\section{Introduction}

The financial crisis of the past three years has seen a dramatic change in the EU financial sector. Since the early 1990s, with the completion of the internal market, there had been a growing move towards an EU financial services market. Banks were becoming more international with greater regional coverage within the EU (and the world). It was anticipated that this integration of the European financial sector would result in a more efficient use of capital in the EU economy, and increased competition. In turn, this was expected to lead to a lower cost of capital, higher investment and, eventually, higher growth. The benefits were expected to arise both from efficiency gains within the sector and also from a more efficient allocation of capital across the economy.

This evolution in the European banking structure in many ways imitated changes in the US that had begun to take place previously. With the introduction of the Riegel-Neal Act (1994), the development of national as opposed to state banks was facilitated. As a result of the savings and loan crisis of the 1980s, there was a concern in the US that banks which were confined to single states were more at risk from idiosyncratic shocks affecting individual states. For example, the Fed in Kansas City saw a major collapse in the banking system in its district because of shocks affecting the local economy, resulting in major insolvencies. The response was to encourage securitisation and geographical diversification in the banking system - a move to bigger and more national banks.

The current financial crisis has seen the collapse of some banks within the EU, and many more have been either partly or fully nationalised because of their inability to deal with their losses. Because of the national basis of banking regulation within the EU it has fallen to individual member governments to rescue 'their own' banks:

- In the UK, the government has had to invest major funds in rescuing Northern Rock and, more importantly, RBS and HBOS. While the problems in RBS arose from a takeover of a Dutch bank, ABN Amro, it was the government of the UK, where the banking group was headquartered, not the Dutch government, that had to foot the bill.

- In the case of Fortis bank, responsibility was shared 
by the Belgian and Dutch governments with the bank being broken up on national lines.

- In the case of the Irish banking system, the government had to nationalise the biggest three national banks and take major stakes in others.

- In Spain the government has had to rescue and reorganise the Caja (savings) banks.

- In Germany the government had to rescue Hypo Bank and support much of the rest of the system.

Thus the EU banking system has seen a major involvement by national governments in capitalising and owning banks headquartered on their territory. But in order to expand and prosper in the future, banks will need more capital. If the markets fail to provide this, then either governments must provide it, or banks will have to survive by gradually reducing the size of their balance sheets.

A big question facing many governments and the EU Commission is therefore whether governments will just recapitalise banks so that they can lend in their own territories or whether they will recapitalise them so that they can operate across their geographical footprint. For example, after the January 2009 EU Finance Council, the UK Chancellor of the Exchequer announced that while the UK government was recapitalising RBS, he was not sure whether they would recapitalise their subsidiary on the island of Ireland - Ulster Bank. It seems that, in the end, they decided to keep Ulster, as it has had an injection of $€ 3$ bn with a further $€ 3$ bn to come to keep them in business. Conversely the Danish government, which has supported Dansk bank, appears to have decided not to recapitalise its subsidiary on the island of Ireland - Northern. The Irish government is requiring AIB to sell off its UK, Polish and US interests to provide some of the capital needed to allow the bank to operate normally in Ireland.

This paper addresses these issues in a systematic way. We first look at the evolving structure of the European banking system, describing the ownership structure as it was in 2009. We then look at how cross-border banking activity has changed, peaking in 2007 and subsequently declining, hinting at a trend towards reterritorialisation. This will imply a reduction in the average scale of banks, particularly in small economies where governments have smaller facilities available for supporting the banking sector and also those where sovereign risk is higher. As small banks tend to charge more for their loans, the user cost of capital will be higher, which will impact on economic activity. After reviewing the literature on EU bank structure, and on net interest margins (NIM), we undertake an empirical analysis of the impact of bank size on the NIM, using a large panel of 713 banks from the BankScope database across fourteen countries and sixteen years. Given these estimates of size on the margin and therefore on borrowing costs, we look at the impacts of reducing bank size on sustainable output in the Euro Area countries using our global model, NiGEM. It is clear from our analysis that small countries are more adversely affected than large ones when bank size falls.

\section{The structure of the European banking system}

We describe trends in the structure of the European banking system before, during and since the crisis in terms of market structure. It appears that European integration to date has chiefly been achieved through the growth of foreign branches and subsidiaries and through cross-border merger and acquisition (M\&A) activity, rather than through the cross-border provision of services. This represents a consolidation of the banking sector internationally, and may have impacted on the outcomes of integration, especially consumer welfare in the EU member countries.

The primary theoretical benefit of financial integration is increased competition; eliminating barriers in the form of national borders increases both the size of the market and the number of firms in the market. Increased competition on the supply side means that banks must improve their services in order to retain their market share. This may take the form of improved quality or lower costs. Furthermore, if integration takes place through expansion of existing banks through foreign branches and subsidiaries, or through mergers and acquisitions, integration is analogous to an increase in bank size. As banks grow larger, up to a certain point they are able to take advantage of economies of scale and scope, which reduces their own funding costs and may allow them to operate more efficiently. In a competitive market environment, this will induce banks to channel these cost advantages into improved lending rates for clients.

Commenting on empirical trends in the sector to date, a report by the European Commission in 2005 (Walkner and Raes, 2005) finds that in most countries a larger 
share of foreign ownership of banks is correlated with a reduction in profitability and margins of domestically owned banks. The report cites Levine (2003), who found that restricting foreign bank entry boosts banks' net interest margins; and Lensink and Hermes (2004), who found that foreign bank entry not only translates into cost benefits for consumers but also enhanced service quality, as foreign firms bring in innovative financial services and practices. There is a possibility that overconsolidation in the financial services market could reduce competition and create a more monopolistic outcome, whereby lower funding costs for banks are channelled into profits rather than lower borrowing costs for consumers. The report notes that, based on the declining trends in net interest margins in the past decade or so, this does not seem to be the case; nevertheless we incorporate such a possibility into our own analysis. Evidence on improvements in efficiency was less clear-cut, possibly due to various institutional barriers imposed by different legal and tax systems across countries for instance, 'preventing exploitation of synergies in cross-border banking' (Vander Vennet, 2002, cited in Walkner and Raes, 2005).

Walkner and Raes (2005) found that it is useful to look at concentration ratios for measuring competition at the domestic level. They took the asset shares of the five largest banks in each country, and found that, with the exceptions of Denmark, Finland and Sweden, all EU member states saw rises in their domestic concentration ratios. The report also looks at an alternative measure of concentration, the Herfindahl index, which considers the size of firms in relation to the industry by looking at the sum of squares of each individual bank's asset shares on a scale of 0 to 10 . Based on this, the authors found that all EU member states except Denmark and Sweden experienced increases. This led them to conclude that, although domestic bank consolidation in Europe has progressed rapidly since the introduction of the euro, cross-border consolidation has in fact lagged behind. Domestic M\&As increase market power of individual firms but cross-border M\&As less so, and therefore the competition benefits of financial integration may not filter through if domestic expansion were to dominate cross-border expansion.

A more recent European Financial Integration Report by the European Commission (2009) reveals that the competition benefits of integration have continued into 2009 , but the recent crisis has brought a focus on domestic activity once more to the fore of the European banking structure. They note that EU financial integration has brought with it benefits to both home and host countries such as increased income generation, improvements in technology and risk management, increased access to funds, risk diversification and deepening of financial markets' (EC, 2009, p. 35). All these are signs of increased innovation, efficiency and lower costs that have been brought about by increased competition and foreign market entry. However, it has been widely observed that these trends were disrupted by the financial crisis in 2007-8. Recent research by the European Central Bank (ECB, 2010) has found that the domination of EU member states' markets by domestic banks has marginally increased since 2007 as foreign (predominantly EU) branches decreased. Domestic credit institutions increased their market share in 2008 ( 73 per cent of total assets were domestically owned) but decreased again in 2009. They also note that crossborder activity was affected; intermediation and merger and acquisition activity declined through 2007-9. The European Commission (2009) similarly observed a segmentation of EU financial markets, and that crossborder (intra-EU) M\&A activity was surpassed by domestic activity in 2008 (both private and government), representing an increased focus on domestic markets, and a decline in the market share of EU branches and subsidiaries. It appears that consolidation resumed in 2008-9, and the number of banks in the EU diminished due to increases in merger and acquisition activity. However, as before the crisis, this activity was channelled mostly into domestic deals. A significant shift in ownership structure towards government participation has taken place in some major EU banks.

As yet it is unclear whether the recent dynamics observed over the crisis period are merely 'temporary entrenchment by market actors within domestic borders' (EC, 2009, p. 17) or whether they actually represent a long-term return to a more segmented and territorialised banking structure. It seems that many of the indicators point to this being a temporary phenomenon. Nevertheless, recent events have called into question the benefits of European financial integration, and though the consensus remains that increased competition can offer clear welfare benefits to consumers, it seems that integration should proceed along more cautious lines. In particular, risk management is clearly now a sensitive issue; it was suggested before the crisis that increased consolidation and an integrated market would lead banks to expand their investment and lending activities across borders, thereby diversifying their portfolios and reducing risk. But integration can instead introduce 
other forms of risk. For instance, an overly-concentrated banking system resulting from domestic rather than cross-border consolidation may be subject to idiosyncratic risk. Walkner and Raes (2005) identified (in advance of the crisis) that foreign bank entry can have negative consequences for macro stability if they ex-patriate capital at signs of domestic distress, thereby causing fragility and imposing lending restrictions on the foreign subsidiary. Integration also exposes banking systems to sovereign risk outside their own borders.

The EC (2009) report cites the experiences of Central, Eastern and Southern Europe (CESE) as a case study for the macroeconomic stability consequences of financial integration. This area saw the largest rise in foreign participation in domestic banking markets, but this has actually reduced diversification and increased concentration in individual markets. The report notes that most CESE countries rely on western European banks for their funding, resulting in a build-up of 'major concentration exposures', whereby the use of 'common funding channels' (in the CESE case, this means Austria and Sweden) increases risk and vulnerability of the funding channel countries to macroeconomic shocks in the host countries. As a result of this, and the 'lack of adequate risk management and regulation', the report notes there were major imbalances in the banking system. Furthermore, the easy access to foreign loans which had previously been seen as conducive to consumption and growth resulted in a speculative property bubble. The report concludes that financial integration has brought clear benefits, but the stability aspects have not received enough attention.

Although it is clear from the European Commission reports described above that consolidation across borders is important for the competitive consequences of integration, what also matters is domestic bank participation in foreign markets. This captures the size of the market on the supply side, rather than bank size. We undertake our own analysis of the structure of the European banking system and how it has changed from this perspective. We firstly consider changes in national market shares as given by the ratio of foreign claims to total assets in the banking system; and secondly, we consider changes in assets held by foreign branches and subsidiaries within the EU. The first indicator shows how cross-border lending has changed over the period between 2000 and 2009, and the second illustrates expansion of banks into other EU countries.

The indicator we use to analyse changes in cross-border banking activity is the ratio of total annual reported claims of foreign banks since 2000 to total Monetary and Financial Institution (MFI) assets. ${ }^{1}$ Information on foreign claims comes from the Bank for International Settlements (BIS) consolidated banking statistics, MFI total assets from the Deutsche Bundesbank. ${ }^{2}$ We present the ratios by country in table 1 , and plot an unweighted average across countries in figure 1 in order to illustrate the patterns of internationalisation and reterritorialisation of banking within Europe. Crossborder activity clearly peaked in 2007 , but this has been reversed in the last two years of our sample.

We then used this indicator to analyse the market shares of foreign claims in 2007 and 2009. Figure 2 plots the changes in shares between 2007 and 2009 to illustrate recent trends. This demonstrates that, while the share of domestic banking in host countries has increased in the majority of countries recently, the change in total foreign market share of lending is negative for almost all countries in the sample, indicating that European banking has become more territorialised and more national since the crisis. The only

Table I. Share of consolidated foreign claims of reporting banks over MFI total assets

\begin{tabular}{lcccccccccccccc} 
& Austria & Belgium & Denmark & Finland & France & Germ. & Greece & Ireland & Italy & Lux. & Neths & Portugal & Spain & UK \\
\hline 2000 & 0.29 & 0.49 & 0.31 & 0.64 & 0.21 & 0.14 & 0.69 & 0.72 & 0.37 & 0.72 & 0.43 & 0.41 & 0.23 & 0.31 \\
2001 & 0.44 & 0.50 & 0.34 & 0.48 & 0.19 & 0.14 & 0.58 & 0.73 & 0.35 & 0.65 & 0.41 & 0.36 & 0.21 & 0.30 \\
2002 & 0.43 & 0.67 & 0.34 & 0.41 & 0.20 & 0.16 & 0.63 & 0.75 & 0.33 & 0.61 & 0.40 & 0.43 & 0.24 & 0.29 \\
2003 & 0.42 & 0.61 & 0.34 & 0.40 & 0.20 & 0.16 & 0.57 & 0.83 & 0.31 & 0.62 & 0.41 & 0.43 & 0.25 & 0.30 \\
2004 & 0.43 & 0.62 & 0.49 & 0.81 & 0.21 & 0.18 & 0.61 & 0.86 & 0.31 & 0.68 & 0.40 & 0.45 & 0.27 & 0.35 \\
2005 & 0.27 & 0.60 & 0.51 & 0.75 & 0.21 & 0.19 & 0.72 & 0.81 & 0.31 & 0.74 & 0.52 & 0.49 & 0.27 & 0.30 \\
2006 & 0.32 & 0.58 & 0.41 & 0.82 & 0.25 & 0.20 & 0.79 & 0.83 & 0.39 & 0.93 & 0.55 & 0.49 & 0.31 & 0.34 \\
2007 & 0.48 & 0.55 & 0.41 & 0.85 & 0.24 & 0.26 & 0.76 & 0.97 & 0.38 & 0.95 & 0.59 & 0.50 & 0.32 & 0.31 \\
2008 & 0.41 & 0.58 & 0.34 & 0.80 & 0.20 & 0.24 & 0.69 & 0.86 & 0.33 & 0.96 & 0.48 & 0.49 & 0.30 & 0.27 \\
2009 & 0.33 & 0.76 & 0.40 & 0.72 & 0.18 & 0.24 & 0.50 & 0.80 & 0.31 & 0.94 & 0.40 & 0.50 & 0.27 & 0.29 \\
\hline
\end{tabular}

Source: BIS, Bundesbank, Bank of England and National Bank of Denmark. 
Figure I. Foreign claims of banks in Europe

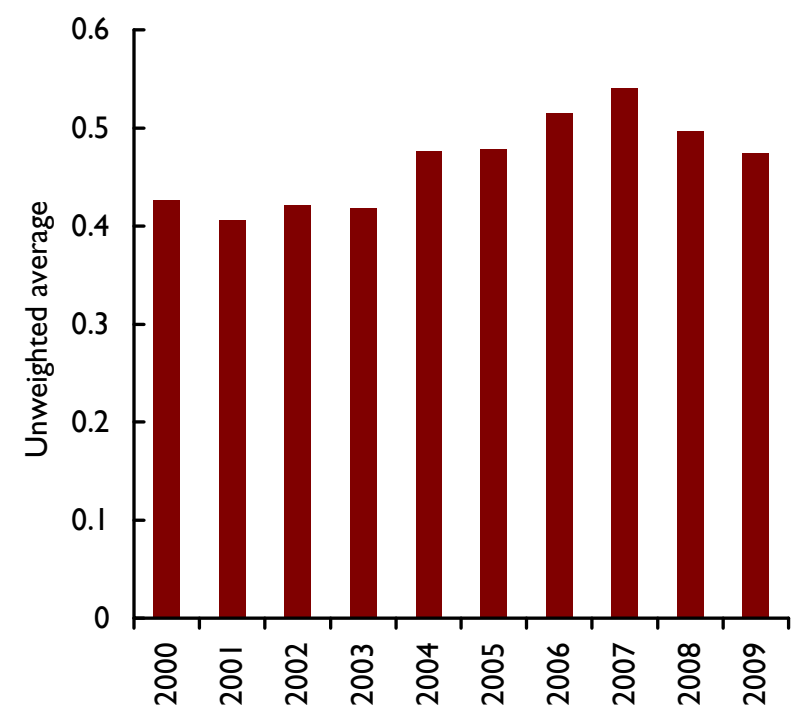

Source: BIS, Bundesbank, Bank of England and the National Bank of Denmark.

Figure 2. Absolute change in the market share of foreign claims between 2007 and 2009

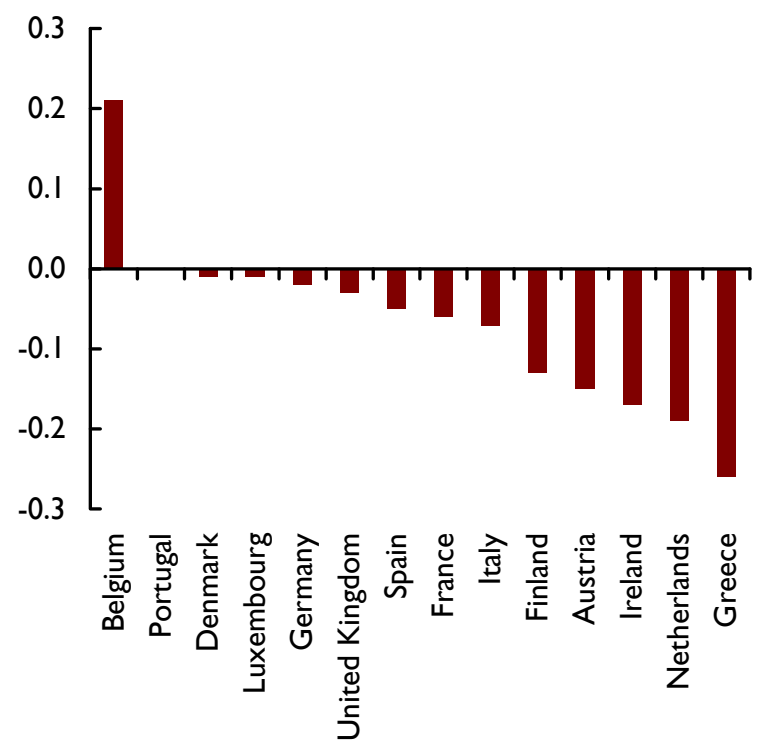

Source: BIS, Bundesbank, Bank of England and the National Bank of Denmark

exceptions to this are Belgium, for which international lending has surpassed domestic banking, and Portugal, whose lending structure remains unchanged.
We can also look at the shares of bank assets held by foreign branches and subsidiaries located in the 27 members of the EU over the period 2003-9, as well as the Euro Area countries and the EU in aggregate. Assets held by foreign branches and subsidiaries indicate the amount of cross-border expansion of banks that has taken place within each country. Estonia, the Czech Republic and Luxembourg are notable for having over 90 per cent of their bank assets held by foreign-owned banks, and hence their domestic banking sectors are almost non-existent. At the other end of the spectrum, larger economies such as France, Germany, Spain and Italy have under 20 per cent of their bank assets held by foreign-owned banks. This figure has not increased since 2003 for France and Spain, whose domestic banks clearly dominate their financial markets. The UK however has over 50 per cent of its bank assets held by foreign branches and subsidiaries, and this figure peaked at nearly 80 per cent in 2005; these particularly large figures signify the importance of the UK as a global financial centre. Cross-border activity through firms and subsidiaries was clearly declining for most countries through 2008 and 2009, illustrating that the effects of the crisis impacted markedly on participation in foreign markets.

Figure 3 plots this data, and divides it into four series showing (i) assets held by all foreign branches and

Figure 3. Shares of assets in EU banks held by foreign branches and subsidiaries

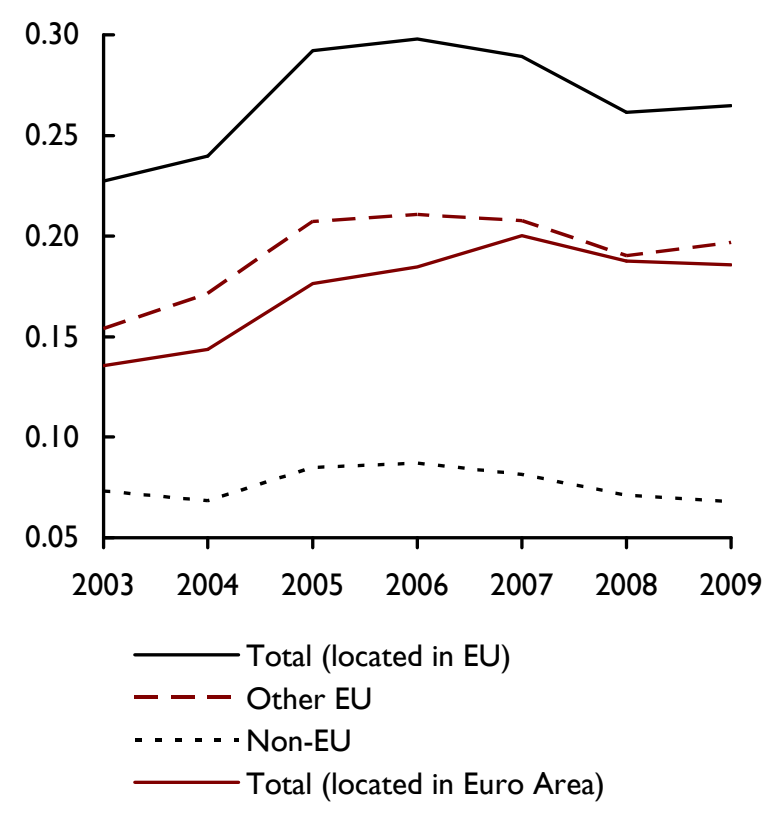

Source: European Central Bank. 
Figure 4. Absolute annual changes in the shares of assets in EU banks held by foreign branches and subsidiaries for the EU

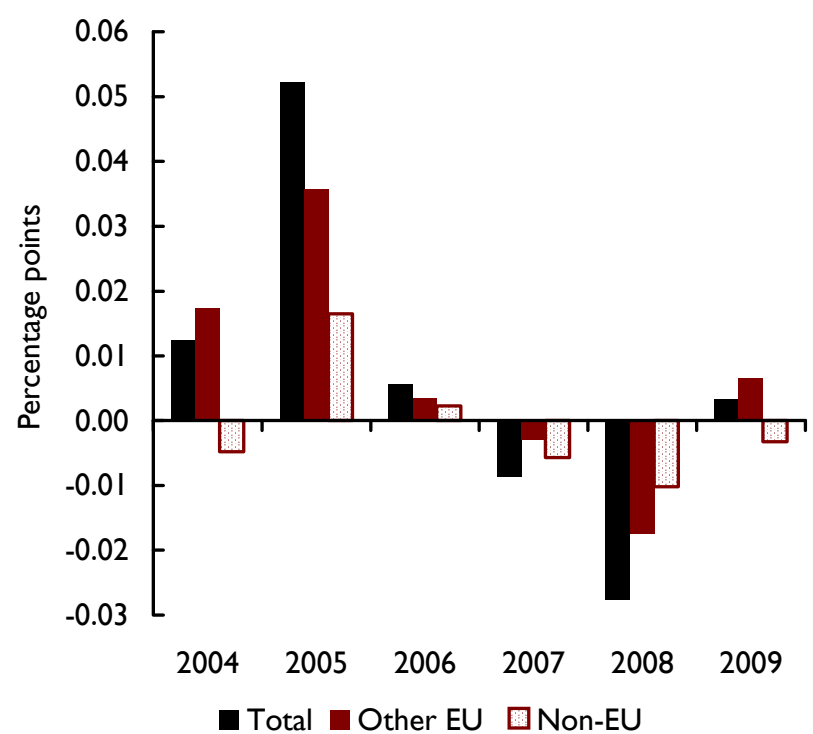

Source: European Central Bank.

subsidiaries located in the EU, (ii) assets held by other EU branches and subsidiaries located in the EU, (iii) assets held by non-EU branches and subsidiaries located in the EU, and (iv) assets held by all foreign branches and subsidiaries located in the Euro Area. The chart illustrates that foreign-held assets peaked in 2005 in the $\mathrm{EU}$, and declined over the crisis years but have started to pick up in 2009. By contrast, foreign-held assets peaked in 2007 for the Euro Area, but have not experienced the positive growth that the EU as a whole experienced in 2009. This is made clearer by figures 4 and 5 , which illustrate the absolute annual (percentage point) changes in assets held by foreign branches and subsidiaries in the EU and the Euro Area; this was positive for the EU in 2009 but was actually still declining in the Euro Area.

The charts also illustrate the driving forces behind recent dynamics seen in EU financial markets. EU branches and subsidiaries clearly make up the bulk of foreign ownership, and hence the decline in overall foreign banking in the EU over 2008 was driven chiefly by the decline in EU branches and subsidiaries (and almost entirely by those in the Euro Area).

Given that borrowing costs have been falling since the 1990 s, we can conclude that the growth in cross-border
Figure 5. Absolute annual changes in the shares of assets in EU banks held by foreign branches and subsidiaries for the Euro Area

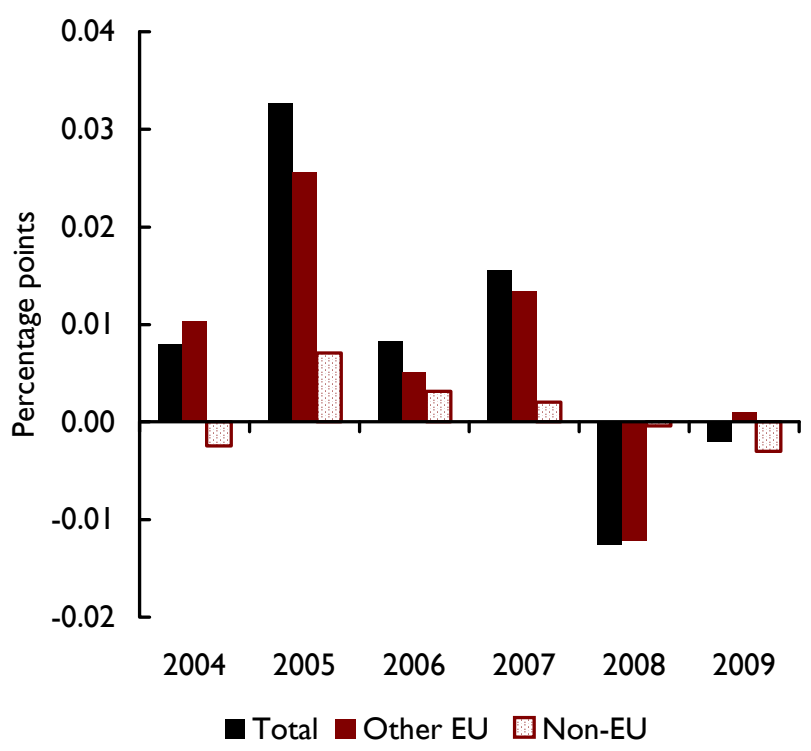

Source: European Central Bank.

banking activity through foreign lending and expansion of foreign branches and subsidiaries within the EU has translated into welfare benefits for consumers. This finding is in accordance with the European Commission and European Central Bank reports described above.

\section{The cost of funds}

As noted, EU banking integration has taken place mainly through merger and acquisition activity and through the expansion of services in other EU countries through branches and subsidiaries. Both of these modes imply growth in the size of banks, and therefore integration can be seen through the perspective of firm size. The key significance that firm size has in the banking sector is the cost of funds; this is the channel through which banking activity influences the economy. However the direction of this influence depends on the amount of market power banks have, as in oligopolistic or monopolistic markets they may not pass on lower costs to consumers. Hence we analyse the relationship between bank size (often measured by asset size) and the net interest margin (NIM), starting with a review of the relevant literature. The NIM is the spread between a financial institution's gross earnings on interest-bearing assets and its interest expenses in funding those assets. It 
can be decomposed into several components - profits, operational costs, regulatory costs and potential costs of default. Each of the components responds to either cyclical or structural shocks, or both. Consequently, it is one of several measures of bank profitability, but moreover captures the functioning of banks generally in terms of efficiency and competitiveness, which in turn impacts on saving, investment and therefore growth (Demirgüç-Kunt and Huizinga, 1999, p. 2). The relationship between the NIM and bank size may consequently be driven by two factors; the earnings side of the spread and the costs side.

With regards to the first, the lending activity of small banks tends to be channelled into small business or personal loans which generate higher yields than larger loans, due to the associated higher expected losses and transaction costs. Furthermore, small banks tend to hold a larger percentage of their asset mix in such loans than in lower-yield investment securities. Large banks, on the other hand, are more able to take advantage of economies of scale, and also perhaps economies of scope in their more diverse array of products. This enables them to offer larger loans at more competitive rates. In addition, they tend to hold a higher proportion of their assets in lower-risk corporate or government bonds. Considering the other side of the spread, small banks often have lower funding costs as they rely on low-

Figure 6. Trends in banks' net interest margins, 19932008

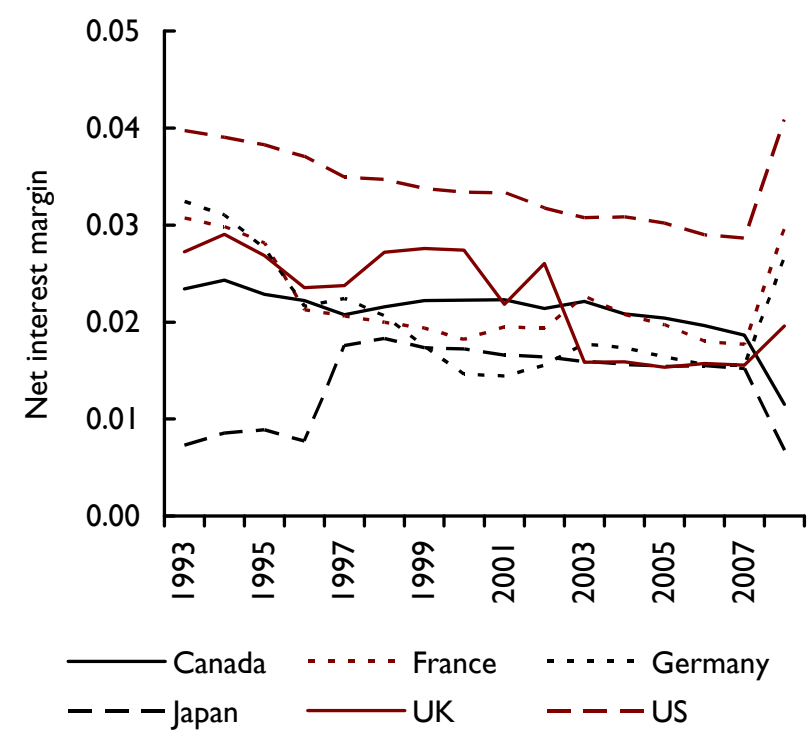

Source: Bankscope. interest core deposits, whereas large banks tend to be dependent on costly and more volatile wholesale funding which is closely linked to the official bank rate. The combination of these characteristics means that the NIM tends to be larger for small banks.

Figure 6 plots the average NIMs across banks in a selection of advanced economies between 1993 and 2008. On the whole, NIMs have been falling throughout this period, indicating that banks may have become larger in these countries or that competition has increased. It may also suggest that banks have been able to lower costs and pass these on to consumers. The crisis years of 2007 and 2008 saw a fairly drastic upwards surge in average NIMs in the European countries depicted and in the US and, if the size-NIM relationship proffered above were to hold, this would indicate a sudden downsizing of banks in response to the crisis. NIMs in Japan and Canada surged in the opposite direction however.

Much of the literature on net interest margins attempts to identify its determinants using an analytical framework that was first developed by Ho and Saunders (1981), in which they modelled bank interest margins as a function of managerial risk aversion, the size of bank transactions, bank market structure and the variance of interest rates. Since then, there have been a number of developments, including a paper by Demirgüç-Kunt and Huizinga (1999), who tested a variety of banking, macroeconomic, regulatory, structural and institutional characteristics as determinants of bank interest margins. They find that larger bank asset to GDP ratios and lower market concentration ratios lead to lower interest margins (substantiating the inverse size-NIM relationship), and more notably perhaps that foreign ownership is associated with higher NIMs (this is more pronounced in developing countries).

Recent literature has begun to look more specifically at the relationship between bank size and the NIM, much of this focusing on Europe as the internationalisation of its banking sector in the five years or so up to 2000 provides an interesting forum for such investigation. Maudos and Fernandez de Guevara (2004) analyse the determinants of the NIM in Germany, France, the UK, Italy and Spain, and find that declining margins in the European banking sector over the period 1993-2000 can be explained by increased market power and concentration as well as interest rate risk, credit risk, operating expenses and bank risk aversion. Market power, concentration and decreased competition are all 
associated with the banking sector becoming more oligopolistic (i.e. fewer, but bigger banks). This substantiates the findings of the EC and ECB reports with respect to how bank size affects the NIM, but goes contrary to what theory suggests regarding the impact of reduced competition on margins.

Kasman et al. (2010) investigate this topic further by examining the effects of bank consolidation in the new European Union members and candidate economies on the determinants of the NIM over two sub-periods, comprising the consolidation period of 1995-2000 and the postconsolidation period of 2001-6. In accordance with the conclusions of the Maudos and Fernandez de Guevara paper, Kasman et al. note that the European banking structure over the entire time period examined was characterised by the cross-border expansion of financial intermediaries and by a 'wave of mergers and acquisitions...[leading to] a reduction in the number of banks in many old and new member countries' (Kasman et al., 2010, p. 649). They find that both bank size and managerial efficiency are significant and exhibit a negative relationship with the NIM over both sub-periods, suggesting that this relationship was robust to the structural changes that took place over this time period.

\section{Econometric analysis}

We approach the same question as that tackled by Kasman et al., which is how the NIM is affected by bank size in Europe in the consolidation period since the 1990s. However we have a dual purpose, which is not only to quantify this relationship but furthermore to use these results to show what would be the economic impact if the recent trend of re-territorialisation and fragmentation of the banking system that was briefly observed through 2007-8 was to continue. We estimate the relationship between bank size and the NIM (where the NIM is approximated by the ratio of net interest revenues to total assets) and model the NIM as a function of cyclical and structural factors.

The set of variables we include in our regression are GDP growth and the real growth of loans, which both capture cyclical fluctuations, the capital adequacy ratio, which is an instrument of regulatory policy, the lagged NIM, and bank size. We use micro data for total assets and loans, and the (risk-adjusted) total capital ratio, all from the Bankscope database over the period 19932008. Our sample excludes central banks, specialised governmental credit institutions and multi-lateral government banks. Macroeconomic data for inflation,
GDP growth and house prices are obtained from national sources as collected in the NIESR NiGEM database.

We use a normalised bank size variable (see Barrell et al., 2010). We calculated the mean and the standard deviation of the bank assets across all countries in each year, and then scaled each bank by the number of standard deviations of its assets from the mean. This accounts for increasing density in the time domain, as the number of banks in our sample rises over time, and hence it is possible that there is a downward trend in average share. Using the NIM as the dependent variable, we estimate over the period 1993-2008 using Ordinary Least Squares. Results of estimation are shown in table 2.

The estimation confirms the results of previous studies reviewed above, namely that bank size negatively affects the NIM; the bigger the bank, the greater its economies of scale and the lower its costs, which allows it to reduce the differential between the lending and the deposit rate. Conversely, the capital adequacy ratio has a positive effect on the NIM, as it increases bank costs. GDP growth and the real growth of loans mirror cyclical fluctuations in the margin, both through profits as well as the potential costs of the default. The default costs can be decomposed into those related to cycle-dependent systemic risk, and those related to bank-size-dependent individual risk (as a bank's portfolio increases, the individual risk falls - and with banks getting larger the probability of a bank having a more diversified portfolio increases). Both GDP and the real growth of loans have a positive effect on the NIM, indicating that it is procyclical.

As noted previously, our central premise that bigger banks can exploit economies of scale in portfolio

Table 2. Regression results

\begin{tabular}{|c|c|c|}
\hline & \multicolumn{2}{|c|}{ Net interest revenues/total assets } \\
\hline & coefficient & t-statistic \\
\hline Lagged dependent (NIM(-I)) & 0.95 & 187.94 \\
\hline GDP growth $(-1)$ & 0.009 & 2.02 \\
\hline Real loan growth $(-1)$ & 0.003 & 7.66 \\
\hline Capital adequacy $(-I)$ & 0.003 & 3.11 \\
\hline Size (normalised) $(-I)$ & -0.006 & -1.99 \\
\hline Observations & 4374 & \\
\hline Banks & 588 & \\
\hline
\end{tabular}

Notes: Fourteen countries in sample, including US and Japan. Two banks dummied out in 2008. 
Table 3. Regression results with nonlinearity variable included

\begin{tabular}{lcc} 
& \multicolumn{2}{c}{ Net interest revenues/total assets } \\
\cline { 2 - 3 } & coefficient & t-statistic \\
\hline Lagged dependent (NIM(-I)) & 0.95 & 184.01 \\
GDP growth $(-I)$ & 0.01 & 2.26 \\
Real loan growth $(-I)$ & 0.003 & 7.63 \\
Capital adequacy $(-I)$ & 0.003 & 2.71 \\
Size (normalised) $(-I)$ & -0.02 & -3.46 \\
Size (normalised)^2 $(-I)$ & 0.003 & 3.21 \\
Observations & 4374 & \\
Banks & 588 & \\
\hline
\end{tabular}

Notes: See table 2.

pooling and thus reduce their NIM holds under perfect competition. However, as bank size increases, monitoring costs may start to rise, and the bank may start behaving as a monopolist. Both of these may mean that margins start to increase above some size threshold. To capture this nonlinearity in the size-NIM relationship, we augment the baseline regression with our bank size variable squared.

The results confirm that, as banks get bigger, they can exploit their increasing market power and also gain from the economies of pooling risk which they pass on to their customers. The relative role of market power is limited however; as bank size increases, bank margins fall until banks are more than four standard deviations above the mean of bank size, which is around 0.15 per cent of the global total. We have computed the threshold bank size above which diseconomies of scale could start playing a role. This value is time-dependent, and also depends on the number of banks in the world banking system. In 2008, if the total assets of a bank exceeded 2.3 per cent of the total assets in the world banking system, the bank could have been considered too big. There was at least one bank in each of the US, UK, Germany, France, Japan and the Netherlands, whose assets exceeded 2.3 per cent of the global assets in 2008. We can examine the effects of different banking systems on the EU economy using our global econometric model, NiGEM.

\section{The structure of the NiGEM model}

The National Institute Global Econometric Model (NiGEM) is structured around the national income identity, can accommodate forward-looking consumer behaviour, and has many of the characteristics of a Dynamic Stochastic General Equilibrium (DSGE) model. Unlike a pure DSGE model however, NiGEM is based on estimation using historical data. What follows is a description of its structural properties.

\section{Production and price setting}

The major country models rely on an underlying constant-returns-to-scale CES production function with labour-augmenting technical progress.

$$
Q=\gamma\left[s(K)^{-\rho}+(1-s)\left(L e^{\lambda t}\right)^{-\rho}\right]^{-1 / \rho}
$$

where is $Q$ is real output, $K$ is the total capital stock, $L$ is total hours worked and $t$ is an index of labouraugmenting technical progress. This constitutes the theoretical background for the specifications of the factor demand equations, forms the basis for unit total costs and provides a measure of capacity utilisation, which then feed into the price system. Barrell and Pain (1997) show that the elasticity of substitution is estimated from the labour demand equation, and in general it is around 0.5. Demand for labour and capital are determined by profit maximisation of firms, implying that the long-run labour-output ratio depends on real wage costs and technical progress, while the long-run capital-output ratio depends on the real user cost of capital

$$
\begin{aligned}
\operatorname{Ln}(L)= & {[\sigma \ln \{\beta(1-s)\}-(1-\sigma) \ln (\gamma)] } \\
& +\ln (Q)-(1-\sigma) \lambda t-\sigma \ln (w / p) \\
\operatorname{Ln}(K)= & {[\sigma \ln (\beta s)-(1-\sigma) \ln (\gamma)] } \\
& +\ln (Q)-\sigma \ln (c / p)
\end{aligned}
$$

where $\mathrm{w} / \mathrm{p}$ is the real wage and $\mathrm{c} / \mathrm{p}$ is the real user cost of capital. The user cost of capital is defined as:

$$
\begin{aligned}
c & =[(1-\mu) *(r+I P R E M) *(1-\text { CTAXR }) \\
& +\mu *(r+P R E M)+\theta] /(1-\text { CTAXR })
\end{aligned}
$$

Equation (4) shows that the user cost of capital is influenced by corporate taxes (CTAXR) and depreciation $(\theta)$, and is a weighted average of the cost of equity finance and the margin adjusted long real rate $(r)$, with weights that vary with the size of equity markets $(\mu)$ as compared to the private sector capital stock. Hence the investment premium (IPREM) directly feeds into firms' borrowing costs and thus their investment decisions.

The NiGEM model contains a description of the banking sector as in Barrell, Davis and Kirby (2010). Bank net 
interest margins feed into the behaviour of individuals and firms through the wedge between borrowing and lending rates. Individuals face LENDW as their spread, and firms face CORPW as theirs. Our work suggests that corporate borrowing spreads charged by banks and bond market premia for corporates move together. We can simulate the effects of changes in bank scale by raising LENDW and CORPW in line with any presumed changes in Net Interest Margins.

\section{Consumption, personal income and wealth}

Consumption decisions are presumed to depend on real disposable income and real wealth in the long run, and follow the pattern discussed in Barrell and Davis (2007). Total wealth is composed of both financial wealth and tangible (housing) wealth where the latter data is available.

$$
\ln (C)=\alpha+\beta \ln (R P D I)+(1-\beta) \ln (R F N+R T W)
$$

where $C$ is real consumption, $R P D I$ is real personal disposable income, $R F N$ is real net financial wealth and $R T W$ is real tangible wealth. The NIM feeds into the consumption decision through real disposable income, which comprises wages, government transfers and receipts on interest-bearing assets owned by the household sector net of borrowing costs. An increase in the NIM indicates a rise in the cost of borrowing, and it therefore reduces real disposable income, impacting negatively on the consumption decision.

The dynamics of adjustment to the long run are largely data based, and differ between countries to take account of differences in the relative importance of types of wealth and of liquidity constraints.

\section{Financial markets}

We generally assume that exchange rates are forward looking, and 'jump' when there is news. The size of the jump depends on the expected future path of interest rates and risk premia, solving an uncovered interest parity condition.

$$
R X(t)=R X(t+1)[(1+r b) /(1+r a)](1+r p r x)
$$

where $R X$ is the exchange rate, $r h$ is the home interest rate set in line with a policy rule, $r a$ is the interest rate abroad and rprx is the risk premium. Nominal shortterm interest rates are set in relation to a standard forward-looking feedback rule, as discussed in Barrell,
Hall and Hurst (2006). Forward-looking long rates are related to expected future short-term rates,

$$
\left(l+L R_{t}\right)=\Pi_{j=l}^{T}\left(l+S R_{t+j}\right)^{l / T}
$$

We assume that bond and equity markets are also forward looking, and long-term interest rates are a forward convolution of expected short-term interest rates. Forward-looking equity prices are determined by the discounted present value of expected profits.

\section{The economic impact of banking system restructuring}

Having established the inverse relationship between bank size and the net interest margin, we now use the NIM to proxy bank downsizing, in order to analyse the impact on output. If banks re-territorialise then the NIM will increase, and will increase the most in small countries because we have a quadratic impact from size on margins, and its impact is steepest for smaller sizes of country. We may write the relationship between the change in size and the NIM as the derivative of the equation in table 3 with respect to size, where $\mathrm{D}(\mathrm{NIM})$ is the change in the net interest margin. Table 3 yields the equation,

$$
\begin{aligned}
N I M= & \hat{a}-0.44 * S I Z E+0.052 * S I Z E^{2} \\
& +\hat{c} * X+\hat{e}
\end{aligned}
$$

where $\hat{c}$ represents a vector of the remaining estimated parameters, and $X$ the remaining explanatory variables in the equation. Hence,

$$
\mathrm{D}(\mathrm{NIM})=-0.44+0.104 * \mathrm{SIZE}
$$

If we reduce bank size in Germany, France, Italy and Spain by two standard deviations, then the NIM will rise by 100 basis points. The largest bank would then be below the maximum efficient scale rather than above it as is the case now. We reduce bank size by twice this in the small countries, the Netherlands, Belgium, Portugal, Greece, Austria and Finland, and given the scale of the Irish banking system relative to its GDP we reduce the average size of banks by an additional amount of the same size. The effects on output are shown in figure 7. We assume that financial markets are forward looking, and equity prices and long-term interest rates jump after a shock. This is because the monetary authorities react to the shock and change interest rates and markets react 
to these changes. We also assume that labour bargains take account of future inflation. Governments set their taxes in order to remain solvent and so when revenues fall, tax rates rise. Furthermore, we assume consumers are myopic and not forward looking. We apply shocks only to Euro Area countries.

There are three sets of factors that affect the long-run impacts on output. Countries with higher capital-output ratios will have larger effects as compared to others, and as a result the effect in Germany is particularly large. However, the long-run effects come through the user cost of capital, and this is the weighted average of equity, bank and bond finance. We are only raising the cost of non-equity finance, and hence France has less effect because private and market equity finance are more important there than in the other large economies. Italy has the largest effect because it has the least developed equity market of the four large economies, and this is reflected in the weights in our user cost equation. Apart from France, the decline in banking sector scale economies reduces equilibrium output by almost 1 per cent. The long-run effects on Greece, Portugal, Austria and Finland are twice as large as this as they are also relatively bank dependent and the shock is twice as large as their banks shrink. The Dutch and Belgians are less reliant on bank finance, and hence the long-run impact of a similar shock is smaller. Ireland faces an even larger increase in margins but, as it is more similar to the UK, with a relatively strong reliance on equity finance, the impacts are muted and are the same size as the bankdependent small economies.

If bank margins were to be increased in this way, these calculations suggest that growth in the Euro Area would be reduced by 0.2 percentage points a year for five years. The short-run effects depend upon the speed of adjustment of the capital stock and on the level of gross borrowing in the economy. If the personal sector has large borrowing as compared to income then a rise in borrowing costs on deposits that is not reflected in income will reduce consumption and demand quickly. Levels of personal sector debt are high in Spain, and adjust more quickly than in other large economies. However if an economy is small and open then most of the effects leak out into imports, as in Ireland, the Netherlands and Belgium, where borrowing has been high, and where income adjusts slowly. However, the overall output in these economies is likely to be larger than average, as we can see from figure 7 .
Figure 7. Effects of raising IPREM and NIM due to decrease in bank size, percentage difference in output from base, 2011

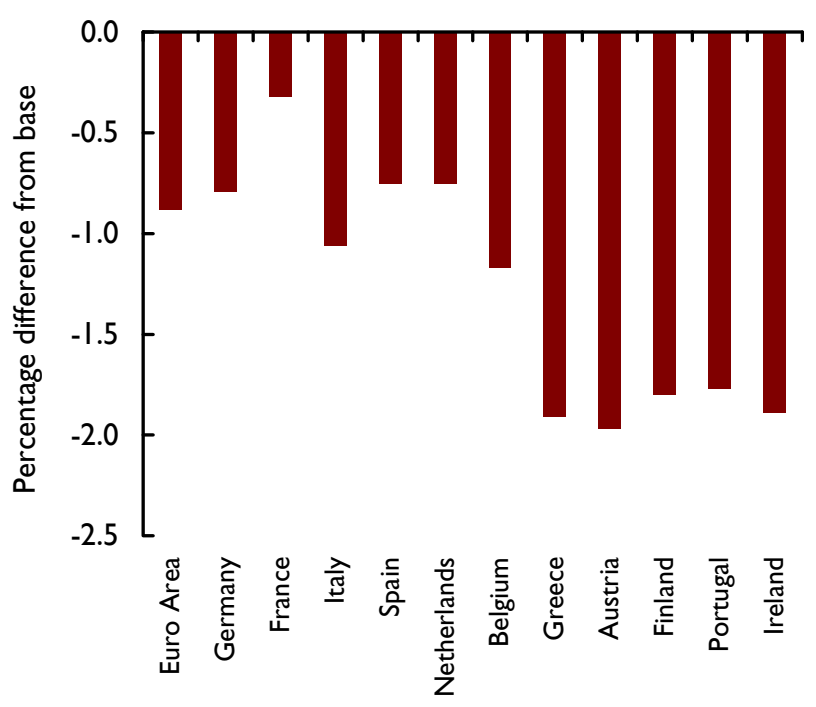

Source: NiGEM.

\section{Conclusion}

The Single Market in Financial Services has meant that banks could become larger in scale, and hence borrowing costs for consumers and for firms will have been lower. We have shown that banks within Europe increased in size and became more international, at least until 2007 when that process went into reverse. We have used a micro data set to investigate the impact of size on banks' net interest margin, and have shown that larger banks have smaller spreads between borrowing and lending rates for firms and households. As we have competition between deposit takers, this largely reflects the fact that they charge their borrowers less. Lower borrowing costs for households raise their incomes and their consumption, whilst for firms lower borrowing costs mean that they raise their investment and this in turn will raise sustainable output. Lower borrowing costs reduce the user cost of capital, and hence increase the equilibrium capital stock, and this would also raise sustainable output. A 1 percentage point reduction in borrowing costs would raise Euro Area output by $1 / 2$ per cent within four years and by $3 / 4$ per cent in the long run. However, this gain from size must also be weighed up against the increase in risky behaviour that is associated with larger banks, as shown by Barrell, Davis, Fic and Karim (2010). 
After looking at the effects of bank size on borrowing costs, we investigate the potential impact of banks moving back into their home territory. In summary, reterritorialisation implies that banks will become smaller, and economies will shrink. We investigate the impacts on output in large and small countries showing that the effects are generally larger in small countries, and also larger in economies that are more dependent on bank finance for their business investment decisions. Our simulations suggest that overall, Euro Area growth would be 0.2 per cent per annum lower for a few years. Competition in banking in the European Single Market in Financial Services has brought benefits and raised output, especially in the smaller economies. However, poor regulation at the Area level and the 'too big to fail' guarantee have meant that the costs may have outweighed the benefits.

\section{NOTES}

I Includes banks whose ultimate owners are located in Australia, Austria, Belgium, Brazil, Canada, Chile, Chinese Taipei, Denmark, Finland, France, Germany, Greece, Ireland, Italy, Japan, Mexico, the Netherlands, Panama, Portugal, Spain, Sweden, Switzerland, Turkey, the UK, and the US. It is necessary to note that ownership is defined here by headquarter location as opposed to shareholder characteristics.

2 Data for Denmark and the United Kingdom were obtained from their respective central banks.

\section{REFERENCES}

Barrell, R. and Davis, E.P. (2007), 'Financial liberalisation, consumption and wealth effects in 7 OECD countries', Scottish Journal of Political Economy, 54, May, pp. 254-67.

Barrell, R., Davis, E., Fic, T. and Karim, D. (2010), 'Is there a link from bank size to risk taking?', NIESR Discussion Paper no. 367.

Barrell, R., Davis, E. and Kirby, S. (20I0), 'Modelling the UK banking sector', National Institute Economic Review, 2I4, October, PP. 67-72.

Barrell, R., Hall, S. and Hurst, I. (2006), 'Evaluating policy feedback rules using the joint density function of a stochastic model', Economics Letters, 93(I), October, Pp. I-5.

Barrell, R. and Pain, N. (1997), 'Foreign direct investment, technological change, and economic growth within Europe', Economic Journal, I07, pp. 1770-6.
Demirgüç-Kunt, A. and Huizinga, H. (1999), 'Determinants of commercial bank interest margins and profitability: some international evidence', World Bank Economic Review, I3, 2.

European Central Bank (2010), EU Banking Structures, ECB, September.

European Commission (2009), European Financial Integration Report, European Commission.

Ho, T.S.Y. and Saunders, A. (I98I), 'The determinants of bank interest margins: theory and empirical evidence', The Journal of Financial and Quantitative Analysis, 16, 4.

Kasman, A., Tunc, G., Vardar, G. and Okan, B. (2010), 'Consolidation and commercial bank net interest margins: evidence from the old and new European Union members and candidate countries', Economic Modelling, 27, 3.

Lensink, R. and Hermes, N. (2004), 'The short-term effects of foreign bank entry on domestic bank behaviour: does economic development matter?', Journal of Banking and Finance, 28, pp. 553-68.

Levine, R. (2003), 'Denying foreign bank entry: implications for bank interest margins', Central Bank of Chile Working Papers, No. 222, August.

Maudos, J. and Fernandez de Guevara, J. (2004), 'Factors explaining the interest margin in the banking sectors of the European Union', Journal of Banking and Finance, 28, 9.

Walkner, C. and Raes, J. (2005), 'Integration and consolidation in EU banking - and unfinished business', European Commission, Economic Paper 226, April.

\section{Appendix}

\begin{tabular}{lrc}
\multicolumn{2}{c}{ Table A I. Country distribution of banks } \\
Country & Banks & Per cent of sample \\
\hline Belgium & 4 & 0.6 \\
Canada & 27 & 3.8 \\
Denmark & 12 & 1.7 \\
Finland & 6 & 0.8 \\
France & 53 & 7.4 \\
Germany & 36 & 5.0 \\
Italy & 35 & 4.9 \\
Japan & 132 & 18.5 \\
Netherlands & 20 & 2.8 \\
Norway & 9 & 1.3 \\
Spain & 48 & 6.7 \\
Sweden & 5 & 0.7 \\
UK & 51 & 7.2 \\
US & 275 & 38.6 \\
Total & 713 & \\
\hline
\end{tabular}

